\title{
The British Museum: An Imperial Museum in a Post-Imperial World
}

\author{
EMILY DUTHIE
}

Consciously or subconsciously, archaeological interpretation and the public presentation of archaeological monuments are used to support the prestige or power of modern nation-states. Neil Asher Silberman, 'Nationalism and Archaeology'

\footnotetext{
7 he British Museum was founded in 1753 as one of the first national, public and secular museum in the world. In Britain, it is the largest and most prominent museum preserving and documenting classical antiquities. However, the acquisition of these ancient artifacts is highly contentious. Increasingly demands for the repatriation of key objects in the museum's collection have appeared in the public arena. Countries including Greece, Egypt and Nigeria maintain that antiquities belong to the particular nations in which they
}

\author{
Public History Review \\ Vol 18 (2011): 12-25 \\ (c) UTSePress and the author
}


were found and demand the return of ancient artifacts to national jurisdiction. The British Museum has rejected most demands for repatriation. Identifying itself as a 'universal museum', ${ }^{1}$ it maintains that it is a global institution with the right to exhibit artifacts from diverse cultures. In this article, I examine the museum in the context of the loss of British imperial power in a now largely post-colonial world. I argue that the museum remains a trope of empire: that it is still an essentially imperialist institution resistant to attempts to dismantle a dominant British culture of the past.

In 1753, Sir Hans Sloane bequeathed the British Museum's founding collection to the nation. A physician and naturalist, Sloane had amassed a vast collection of 'plants, fossils, minerals, zoological, anatomical and pathological specimens, antiquities and artificial curiosities, prints, drawings and coins, books and manuscripts. ${ }^{2}$ His private collection at his country mansion in Chelsea received a number of notable visitors, including Handel and the Prince and Princess of Wales. The Prince emphasised the importance of this 'treasure house' and 'expressed the great pleasure it gave him to see so magnificent a collection in England, esteeming it as an ornament to the nation; and how much it must conduce to the benefit of learning and how great an honour will redound to Britain to have it established for public use to the latest posterity. ${ }^{3} \mathrm{His}$ remark was prescient. When Sloane died, he left his collection of 79575 objects to the nation. On 7 June 1753, King George II gave his formal assent to the Act of Parliament that established the British Museum. Two other collections were also brought under the care of the museum at this time: the Cottonian Library of books assembled by Sir Robert Cotton and the Harleian collection of manuscripts from the Earls of Oxford. These were joined in 1757 with the Royal Library. ${ }^{4}$ The collection was originally held in Montagu House, a converted seventeenth-century mansion. The British Museum's present building, designed in the Greek revival style by Sir Robert Smirke, was built on the site of Montagu House between 1823 and 1852. ${ }^{5}$

The British Museum's specialised interest in classical antiquities began as early as 1772 when the museum acquired a collection of Greek vases belonging to Sir William Hamilton. ${ }^{6}$ Other notable objects acquired included the first ancient Egyptian mummy donated to the museum in 1756 as well as a number of ethnographic artifacts given to the museum after Captain Cook's three Pacific voyages (1767-70). The Rosetta Stone was acquired in 1802 and the Townley collection of classical sculpture, including the Discobolosa statue and the bust of a young woman at Clytiea was accessioned in $1805 .^{7}$ The importance of ancient artifacts was 
officially recognised when the Department of Antiquities was founded in 1807.8

In a brochure for the public, under the rubric, 'Don't miss', the museum currently promotes the following objects: the King of Ife, the Rosetta Stone, the Parthenon sculptures, the Assyrian lion hunt reliefs, mummies, Oxus Treasure, the Royal Game of Ur, Lewis chessmen and Samurai armour. The Elgin Marbles, the Rosetta Stone and the Benin Bronzes are its most famous objects. ${ }^{9}$ In 1860, the Department of Antiquities was divided into three new departments that reflected the priorities of the collection: Greek and Roman Antiquities, Coins and Medals and Oriental Antiquities. ${ }^{10}$ So preoccupied was the museum with ancient artifacts that it was not until the appointment of the curator, Augustus Franks, in 1851 that the Museum began for the first time to collect British and European medieval antiquities. ${ }^{11}$ Promoting itself as a 'universal collection', the museum was now accumulating both western and non-western objects. In a British Museum publication, The Story of the British Museum, Marjorie Caygill, the Assistant Keeper at the museum, declares that at the height of empire in the nineteenth century

it was possible for the inquisitive visitor to Bloomsbury to see the 'cabinet of curiosities' in which a section of an old palace near Moscow was displayed next to earthenware from Southern America, figures of German miners, Chinese and 'other shoes'; where, before modern principles of classification imposed an element of uniformity... Chinese bows and arrows and snow shoes were thought to be fit companions for King William and Queen Mary cut in walnut shells and a landscape painted on a spider's web, not to mention the jaw and other parts of an unknown animal from Maastricht, stones from the bladders of horses and hairballs from the stomachs of cows. ${ }^{12}$

Undoubtedly, Caygill's remark is typical of the modern British Museum's depiction of itself as an enlightened institution and 'an ordered representation of the world in miniature. ${ }^{13}$

As a custodian of cultural objects, the museum's professed aims appear to be highly altruistic. On its official website, it is called a 'museum of the world, for the world'14 and the museum's present director, Neil McGregor, declares that it is for 'all mankind. ${ }^{15}$ Its collections also include representative examples of the world's artistic legacy prompting James Cuno, the director of the Art Institute of 
Chicago, to argue that 'encyclopaedic museums' like the British Museum effectively direct attention to distant cultures and enhance historical knowledge ${ }^{16}$ In the contemporary British press, McGregor has been widely credited with redefining the role of the British Museum in public life. He emphasises the importance of an international community of enquiry, maintaining that his museum is 'not a Eurocentric one, and the public perception is not overwhelmingly Eurocentric... We have a way of thinking about the whole world. ${ }^{17}$ He notes that from the museum's beginnings 'the objects were to be available free of charge to all "studious and curious persons" and were stated explicitly to be for foreigners as well as natives. ${ }^{18}$ However, such statements quietly elide the relevance and importance of colonial history in the creation and development of the British Museum. Imperialism is part of the Bloomsbury story. Ostensibly, McGregor has introduced an 'egalitarian ethos' to the museum. The Sunday Times observed in 2007 that the museum has evolved from being an 'imperial war chest' to a 'global resource. ${ }^{19}$ However, such claims are historically weak and are open to challenge.

In the nineteenth century, the museum was a powerful symbol of empire and the representations of the world that it offered were deeply imbued with the culture of British imperialism. As Barringer and Flynn observe, it was an 'imperial archive' and 'the most spectacular repository of the material culture of empire. ${ }^{20}$ The meaning of an object is inflected and even re-invented by the context in which it is displayed. Thus, the removal of objects by the British Museum from a 'colonial periphery' to an 'imperial centre' changed the ways in which they were interpreted. ${ }^{21}$ The movement of objects to the 'centre' symbolically enacted the idea that London was the heart of the empire. As a correspondent wrote of the British Museum in 1837: 'There is not a better sight in London; there are few places better worth seeing in the world. ${ }^{22}$ More recently, Tim Barringer and Tom Flynn wrote: 'The British Museum could never be restricted to British things, for to do so would set a limit to the reach of British power, as well as to the gaze of the all-comprehending and autonomous subject. ${ }^{23}$ This ideal is also made manifest in Moncure Conway's book, Travels in South Kensington, which was written in 1882:

'Come' said my friend, Professor Omnium, one clear morning, 'let us take an excursion round the world'... 'My dear friend', said I, 'it is among my dreams one day to visit India, China, Japan, California, but at present you might as well ask me to go with you to the moon.' 'You misunderstand', replied Professor Omnium. 'I do not 
propose to leave London. We can never go round the world, except in a small, limited way, if we leave London... Ten thousand people and a dozen governments have been at infinite pains and expense to bring the cream of the East and the West to your own doors. $^{24}$

Museum building in Britain in the nineteenth century was a direct consequence of war, colonialism and missionary expeditions, which returned with 'exotic' objects. In London, museums were built after successful colonial ventures with displays of empire and the hope that such displays, like the empire itself, would be a lasting achievement. A poem composed for the opening of London's Imperial Institute vaunted the 'Empire of a Thousand Years. ${ }^{\prime 25}$

Many of the ancient treasures in the British Museum were 'acquired' through aggressive and opportunistic looting and plundering and by the fraudulent 'purchasing' of objects. Sir Aurel Stein's removal of a whole library of ancient Chinese documents from the Dunhuang Caves in China in 1907 is, in Simon Winchester's words, 'a grisly example of western perfidy. ${ }^{26}$ For a paltry sum of $£ 220$, Stein persuaded the monk, Wang Yuanlu, to sell the entire contents of the caves. He took at least twenty-four wagonloads of papers and thousands of ancient objects, comprising one of the richest finds in archaeological history - including the Diamond Sutra, the world's earliest known printed book. ${ }^{27}$ The British Punitive Expedition against Benin in 1897 is another typical case of imperial aggression that resulted in the plundering of art. ${ }^{28}$ The Benin bronzes, a collection of more than a thousand brass plaques were seized by a British force from the royal palace of the Kingdom of Benin (now part of Modern Nigeria) and given to the British Foreign Office. Around two hundred of these were given to the British Museum. Similarly, the acquisition of the Parthenon Marbles in Athens was the result of opportunism. Thomas Bruce, the seventh earl of Elgin, had originally intended only to take back to Britain drawings and moulds of Classical Greek antiquities. However, between 1801 and 1812, he removed a number of sculptures from the Parthenon in Athens and sent them to London. ${ }^{29}$

The practice of plundering artifacts from their original setting is sometimes referred to as 'elginism ${ }^{30}$ because of the damage that Elgin caused. The Parthenon and the Erechtheum and many of its decorations were sawn in half to reduce their weight and to facilitate their transport. Thus, the column capital of the Parthenon, the Erechtheum cornice and many metopes and slabs were destroyed. Elgin's rapacity was shared by 
his associates. Thomas Lacy suggested the removal of the entire Pandrossium and expressed his regret that the transport of the pieces he found in Olympia would be too expensive while Philip Hunt was disappointed that the two lions over the gate at Mycenae were too heavy to remove. ${ }^{31}$ Christopher Hitchens, a leading advocate for the return of the so-called 'Elgin Marbles' and other antiquities, argues that these objects were removed from their natural environment and from the space that they were intended to occupy. ${ }^{32}$ When an ancient work of art is removed from its original setting, its value and archaeological interest remain. However, if left in situ it constitutes an aesthetic and historical entity.

Due to its international standing and the historical significance of its collections, the British Museum has been the target for most repatriation requests in the United Kingdom. Between 1970 and 1999, it received twenty-seven foreign requests for repatriation. ${ }^{33}$ At the same time, the climate of opinion has increasingly become one of greater willingness to at least consider the possibility of returning certain objects in western museums to their place of origin. The main impetus for repatriation has come from former colonies in which indigenous, minority and suppressed cultures were unable to resist the original removal of historical objects. Their relationship with dominant western powers has changed, as they are now sovereign entities in their own right and able to defend their cultural property. Greece, Egypt and China have enacted strict cultural property laws investing ownership of antiquities found or thought to have been found within their state jurisdiction - they are state property and their export is forbidden without state permission. ${ }^{34}$

There is now a widespread recognition among museum professionals throughout the world that museums should treat the material products of other cultures as more than 'exotica' or 'primitive' curios. As Robert Aldrich observes: 'Most European countries wanted to move on from the imperial age, pushing the ideas that had underpinned imperialism out of the way and sometimes wilfully forgetting the imperial past and neglecting its legacy.' ${ }^{35}$ This process has been particularly assertive in colonised countries in which indigenous populations were dispossessed. The Commonwealth Institute, the Museum of African and Oriental Arts, Amsterdam's Tropenmuseum and the Africa Museum have all overturned colonialist language and imagery in their galleries. However, despite considerable pressure from foreign governments, the British Museum has refused to follow suit and return the art and antiquities that it acquired under the aegis of empire. Its position encapsulates the challenges inherent in presenting empire 
and its legacy to contemporary, post-imperial audiences. Having inherited a colonial collection, the trustees of the British Museum are faced with the multi-faceted problems of exhibiting an imperial heritage within a post-imperial context. Robert Aldrich describes this predicament of imperial institutions: 'When the colonial flags were lowered, what was to become of museums that lost their very reason for being? ${ }^{36}$ In the case of the British Museum, persistent claims to ancient heritage and its inflexible response to demands for repatriation reinforce its past imperialist policies.

Since his appointment in 2002, McGregor has tried to overturn this perception of the museum as the quintessential imperial institution, looting the world and acquiring the trophies of global power for the glorification of Britain. The museum's policy of $2007^{37}$ stipulates that it will comply with the principles set out in Combating Illicit Trade: Due Diligence Guidelines for Museums, Libraries and Archives on Collecting and Borrowing Cultural Material (2005). The museum will not acquire objects unless they are legally available for acquisition. If the museum is in any doubt it will not proceed with the acquisition. Nor will the museum accept any object without obtaining the confirmation of the donor, executor or seller that he or she owns the object and is able to transfer it. The museum adheres to the Convention on the Means of Prohibiting and Preventing the Illicit Import, Export and Transfer of Cultural Property (1970); the Return of Cultural Objects Regulations (1994); the Dealing in Cultural Objects Act (2003); and the Treasure Act (1996). In its official policy, the museum condemns the looting of antiquities and damage to archaeological sites. It no longer acquires objects that are known to result from such looting and will usually only acquire archaeological and heritage objects that have documentation to show a legal history back to the UNESCO Convention of 1970. The Museum's official policy concludes with a declaration that it will 'pay due respect to the moral rights of other individuals, groups or organisations. ${ }^{38}$

However, despite its recent legislation, the museum insists that the objects acquired under the British Empire are now part of the museum and, more broadly, the cultural heritage of the nation. As the museum's acquisitions policy states, its antiquities were legitimately accrued 'in the light of the period during which the material was acquired. ${ }^{39}$ The British Museum remains unapologetic about the history of its early collections and fails to reconcile its current policies with its past acquisitions. In The Guardian Neil McGregor even referred to repatriation as 'yesterday's question... Questions of ownership depend on the thought that an object can only be in one place. That's no longer true. ${ }^{40}$ Moira Simpson rightfully refutes this dismissive attitude: 
If museums are to demonstrate that they have shaken off the colonial mantle, they must address fully the issue of repatriation. To have a blanket 'no returns' policy reflects a failure to recognise or acknowledge the relevance of the concepts of spiritual ownership, cultural patrimony and the cultural importance of certain objects to cultures that did not die out in the nineteenth century, as was expected. ${ }^{41}$

Defending the founding practices and principles of the British Museum, the present trustees have retained this 'colonial mantle.' As well, the 'redefinition' of the principles of the British Museum as a universal museum has had some interesting manifestations in the last few years. In 2008, The Times declared that the 'British Museum is the best in the world ${ }^{42}$ and in a series of well-orchestrated anniversary celebrations, exhibitions and media events in 2003, the British Museum sought to reinforce its eighteenth-century Enlightenment identity as a universal museum - a showcase of the finest achievements of world 'civilisation', which could be surveyed as a grand historical narrative. Central to this effort was Neil McGregor's decision to assemble parts of the museum's collections that had been dispersed throughout London in order to reunite them with the main collection. Many of these objects had been collected by the museum under the British Empire for national selfcongratulation and self-satisfaction. As McGregor declared: 'We'll be back to 1753 with the whole world under one roof. ${ }^{\prime 43}$

Another effort to 'share' its collection was made in 2005 when the British Museum funded an exhibition called 'Hazina: Traditions, Trade and Transitions in Eastern Africa' in order to create stronger cultural links with Africa. According to McGregor: 'It has told the story of the region, the links between cultures over centuries and the things that tie those cultures together. ${ }^{44}$ A circumcision mask from western Kenya and a headdress made from human hair from Uganda were among the 140 artifacts from the British Museum that were displayed in Nairobi - the first time the museum has lent objects to Africa. However, the exhibition sparked debate about whether such objects should be returned to their home countries: 'We feel this is going to be the central theme [of debate]: why are these objects, which come from here, kept in Britain?', said Idle Omar Farah, director-general of the National Museums of Kenya. ${ }^{45}$ Farah hoped that by providing adequate security and environmental conditions for the artifacts he might eventually secure longer-term loans for the National Museum's Nairobi base. According to Kimani wa 
Wanjiru, of the Nairobi-based Standard newspaper, most of the objects were taken during the colonial period: 'We have to ask, what were the circumstances under which they were taken? How were the objects used? What "knowledge" was extracted from them?'46

In response to such questions, the British Museum asserts that it is an appropriate 'custodian' with an inalienable right to its disputed artifacts under British law. Central to its stance on issues of cultural ownership and repatriation is its claim that the museum's founding legislation prevents them from deaccessioning material from collections:

$1^{\text {st }}$. That the collection be preserved entire without the least diminution or separation. $2^{\text {nd }}$. That the same be kept for the use and benefit of the public, who may have free access to view and peruse the same, at all stated and convenient seasons agreeably to the Will and intentions of the Testator, and under such restrictions as the Parliament shall think fit. $^{47}$

More recently, the British Museum Act of 1963 prohibited the museum from selling any of its valuable artifacts, even the ones not on display. ${ }^{48}$ A legalistic approach has been applied as leverage in obtaining returns or stemming the illicit flow of art treasures. However, the British Museum does not assume this approach. While Australian and American legislative changes give indigenous populations ownership over the remains of deceased ancestors, under British law there is no right of ownership over human remains. ${ }^{49}$ In Britain, the matter of repatriation has not received formal consideration from the Museums and Galleries Commissioners. This was demonstrated in the British High Court in May 2005 in relation to Nazi-looted artworks held at the museum. It was ruled that these could not be returned. The judge, Sir Andrew Morritt, ruled that the British Museum Act cannot be overridden by a 'moral obligation' to return works known to have been plundered. ${ }^{50}$

The British Museum's other claims to classical antiquities are implicitly imperialistic, particularly its argument that cultural artifacts should remain in London because it is Europe's largest and most visited city. Advocates of universal museums maintain that cultural treasures should be stored where they can be visited by a large number of people. By maintaining a worldwide-oriented collection in one location, the British Museum prides itself on being a 'world heritage centre', a 'central meeting-point' and 'the whole world in one building. ${ }^{.51}$ It maintains, too, that the museum provides a valuable context for objects that have been 
displaced from their original source. Cuno argues that the museum's objects benefit from their setting, where they can be seen free of charge alongside other artifacts from all over the world ${ }^{52}$ The British Museum is concerned that if restitution demands were met, the world's great museums would be emptied. ${ }^{53}$

Underpinning the museum's position is the assumption that the source nations of antiquities are unable to house and maintain their own objects and that they need London to preserve their history and heritage. In defending its refusal to lend the Elgin marbles to Athens, the British Museum recently adopted the position that it is a better custodian of ancient antiquities than Greece. Dorothy King, who advocates the retention of the Elgin Marbles in Britain, declares: 'The Greek government's attitude to its history and culture leave much to be desired... Through its apathy and indifference it has allowed many of the sculptures and monuments in its care to become damaged. ${ }^{54}$ In its various publications on the Parthenon Marbles, the British Museum presents Elgin as a 'lover of antiquity ${ }^{55}$ dedicated to rescuing the Athenian sculptures from destruction. In his discussion of the acquisition of the Rosetta Stone, Cuno claims that Egypt had little regard for the land's ancient heritage, and that until the final decades of the nineteenth century, Egyptians showed little interest in their ancient past, despite the evidence of it all around them. Cuno suggests that it was only after Europe found the Rosetta Stone and deciphered its hieroglyphics that the Egyptians became interested in their ancient heritage. ${ }^{56}$ Both the British Museum and its supporters argue that the Museum has provided protection for artifacts that would have been damaged or destroyed if left in their original environment.

Although this may have been true at the time, it does not necessarily pertain today. Hitchens, Greenfield and Robin Rhodes, among others, declare that the artifacts should now be returned to their countries of origin if there is sufficient expertise and desire there to preserve them. ${ }^{57}$ British claims that Greece would have nowhere to display the Parthenon Marbles if they were returned are no longer relevant. In 2008, the Acropolis Museum in Athens ${ }^{58}$ was completed to house them. The museum is equipped with sophisticated technology for the protection and preservation of exhibits. The marbles are well lit in the top floor of the museum and exhibited under the natural sunlight that characterises the Athenian climate, in the way that the Ancient Greeks intended them to be seen. About half of the sculptures, inscriptions and architectural columns from the Parthenon are now displayed in the museum. However, a visitor to the museum is instantly drawn to a series of veiled 
plaster casts representing the absent marbles housed in the British Museum without natural light.

For as long as classical antiquities are displayed in the British Museum it is inevitable that they will be interpreted from a British point of view. The museum is primarily a British institution. It was established by a British Parliamentary Act for the British people. As The Times wrote in 2008, the British Museum is 'an iconic national establishment... the first public institution to be called British and the oldest British organisation. ${ }^{59}$ While the museum uses its Greek, Egyptian and Chinese objects to represent and interpret these ancient civilisations, by rejecting repatriation requests, it does not allow nation states to formulate their own interpretations. As Philip Kohl suggests, the colonised and the conquered have been deprived of objects that are central to their historical narratives of identity. ${ }^{60}$

Classical antiquities serve the interests of a nation by contributing to the formation of historical and nationalist narratives. Museum objects foster the self-esteem of the nations in which they were created and discovered and source nations frequently invoke cultural nationalism when they make their requests for repatriation. The Greek government, for instance, believes that the Parthenon Marbles are inherent to Greece's history and culture, declaring: 'They embody its spirit and connect modern Greeks to their ancient ancestors and confirm ancient legitimacy on their modern government. ${ }^{61}$ In 1983, the Minister of Culture in Greece, Melina Mercouri, expressed this notion in very emotive terms: 'This is our history, this is our soul. They are the symbol and the blood and the soul of the Greek people. ${ }^{62}$ Similarly, Zahi Hawass, the director of the Supreme Council of Antiquities in Cairo, insists that the Rosetta Stone should be returned to Egypt because 'it is the icon of our Egyptian identity. ${ }^{63}$ The Stone's significance lies in the role it played in deciphering ancient Egyptian hieroglyphs from which the history of ancient Egypt has been written as the origins of modern Egypt. In the same vein, Nigeria insists that the Edo people used the Benin Bronzes to mark important dates in their history and that the removal of these objects left a vacuum in the records of Benin history. The centennial of the British expedition in Benin in 1997 emphasised the fact that Benin artifacts were still housed in overseas museums and this issue became the focus for a campaign at that time. A major exhibition of African art at the Royal Academy was targeted as a means of highlighting the circumstances under which some items in museum collections were acquired. On their website, the African Reparations Movement showed images of African artifacts that were included in the exhibition, declaring 
that many of them had been acquired by theft. It displayed the photographs emblazoned in red lettering with the word stolen!' ${ }^{64}$

These debates and the British Museum's response highlight crucial issues about the role and function of museums in general and the ownership of works of art in particular. As John Merryman, Professor of Art at Stanford University astutely observes, collecting art has always been the domain of the rich, including individuals and nations. Power is a major factor that has distributed art around the globe..$^{65}$ The issues of who owns antiquity are highly complex. 'Unprovenanced' ${ }^{\prime 66}$ antiquities are ones with gaps in their chain of ownership. Antiquities have sometimes originated in cultures that are no longer extant or are of a very different kind from the modern, national culture claiming them. When the Rosetta Stone was acquired, for example, there was no independent state of Egypt: 'What is the relationship between, say, modern Egypt and the antiquities that were part of the land's Pharaonic past? The people of modern-day Cairo do not speak the language of the ancient Egyptians, do not practise their religion, do not make their art, wear their dress, eat their food, or play their music, and they do not adhere to the same kinds of laws or form of government the ancient Egyptians did. All that can be said is that they occupy the same... stretch of the earth's geography. ${ }^{67}$ However, well known cases that have been outstanding for many years, including the Greek government's claim for the return of the Parthenon Marbles and Nigeria's calls for the return of the Benin artifacts are less ambiguous. It should be possible to claim legally all materials that have been taken by force, by unequal treaty, by theft or by fraud.

Cultural property and its stewardship have long been the concerns of museums, archaeologists, art historians and nations, but recently the legal and political consequences of collecting antiquities have also attracted public attention. In this climate, the British Museum, a former imperial museum, is compelled to re-examine the role that it can and should play today. Despite its claims that it has re-defined its public image, the museum's attempted transition to a post-imperial context has been confused and deeply uneasy. It remains an imperial institution in a post-imperial world. By retaining the museum's original philosophy and principles, the museum is reenacting the attitudes and ethics of its imperial founders. As Moira Simpson writes, the museum is 'a mirror reflecting the views and attitudes of dominant cultures, and the material evidence of the colonial achievements of the European cultures in which museums are rooted. ${ }^{68}$ 


\section{Endnotes}

${ }^{1}$ What Does it Mean to be a World Museum? Celebrating the 250th Anniversary of the Public Opening of the British Museum: A Lecture by Neil McGregor. (Online). Available: http://www.britishmuseum.org/the museum/museum in london/event archive/250 lect ure.aspx (Accessed 11 Apr. 2010).

2 British Museum, The British Museum and its Collections, British Museum Publications, London, 1982, p5.

${ }^{3}$ Arthur MacGregor, Sir Hans Sloane: Collector, Scientist, Antiquary, Founding Father of the British Museum, British Museum Press, London, 1994, p47.

${ }^{4}$ A. E. Gunther, 'The Royal Society and the Foundation of the British Museum, 1753-1781', in Notes and Records of the Royal Society of London, vol 33, no 2, 1979, p209.

${ }^{5}$ Marjorie Caygill, The Story of the British Museum, British Museum Press, London, 1981, p23.

${ }^{6}$ Edward Miller, That Noble Cabinet: A History of the British Museum, Ohio University Press, Ohio, 1974, p100.

${ }^{7}$ Antonio Paolucci, Great Museums of Europe: The Dream of the Universal Museum, Skira, Milan, 2002, p124.

${ }^{8}$ Miller, That Noble Cabinet: A History of the British Museum, p299.

${ }^{9}$ See the British Museum's website. Available: http:// www.britishmuseum.org/learning/families and children.aspx (Accessed 11 Apr. 2010).

${ }^{10}$ British Museum - History of the Collection. (Online). Available: http://www.britishmuseum.org/the museum/history and the building/history of the co llection.aspx (Accessed 11 Apr. 2010).

${ }_{11}$ Marjorie Caygill, Treasures of the British Museum, H.N. Abrams, New York, 1985, p199.

${ }^{12}$ Caygill, The Story of the British Museum, p3.

${ }^{13}$ Tim Barringer and Tom Flynn (eds), Colonialism and the Object: Empire, Material Culture and the Museum, Routledge, London, 1998, p11.

${ }^{14}$ See the British Museum's website. Available: http:// www.britishmuseum.org/the museum.aspx (Accessed 11 Apr. 2010).

15 'Neil MacGregor Lifts British Museum's Ambition to New Heights,' The Times, 18 July 2009.

${ }^{16}$ James Cuno, Who Owns Antiquity? Museums and the Battle over our Ancient Heritage, Princeton University Press, Princeton, 2008, pxix.

${ }^{17}$ Bryan Appleyard, 'Behind the Scenes at the British Museum: From Imperial War Chest to Global Resource - the British Museum's latest plan, suggests its director, Neil MacGregor, is to let everyone write their own history.' The Sunday Times, 6 May 2007.

${ }^{18}$ What Does it Mean to be a World Museum? Celebrating the 250th Anniversary of the Public Opening of the British Museum: A Lecture by Neil McGregor.

${ }^{19}$ Appleyard, 'Behind the Scenes at the British Museum: From Imperial War Chest to Global Resource.' The Sunday Times, 6 May 2007.

${ }^{20}$ Barringer and Flynn (eds), Colonisation and the Object: Empire, Material Culture and the Museum, p27.

${ }^{21}$ ibid, p12

${ }^{22}$ Quoted in Caygill, The Story of the British Museum, p66.

${ }^{23}$ Barringer and Flynn (eds), Colonisation and the Object: Empire, Material Culture and the Museum, p43.

${ }^{24}$ Moncure Daniel Conway, Travels in South Kensington, Harper and Brothers, London, 1882, pp21-3.

${ }^{25}$ See Chris Brooks and Peter Faulkner, The White Man's Burden: An Anthology of British Poetry of the Empire, Exeter University Press, Exeter, 1996, p285.

${ }^{26}$ Simon Winchester, The Man who Loved China: The Fantastic Story of the Eccentric Scientist who Unlocked the Mysteries of the Middle Kingdom, Harper Collins, New York, 2008, p138.

${ }^{27}$ ibid, p138.

${ }^{28}$ For descriptions of this acquisition, see Philip Dark and Forman Werner, Benin Art, Hamlyn, London, 1960; Jeanette Greenfield, The Return of Cultural Treasures, Cambridge University Press, Cambridge and New York, 1989, pp141-48; Eko Eyo, 'Repatriation of Cultural Heritage: The African Experience', in Flora Kaplan (ed), Museums and the Making of 'Ourselves': The Role of Objects in National Identity, Leicester University Press, London, 1994, pp 335-42; Ormande Dalton and Charles Read, Antiquities from the City of Benin and from other Parts of Africa in the British Museum, British Museum Press, London, 1899.

${ }^{29}$ For descriptions of the removal of the Elgin Marbles, see B.F. Cook, The Elgin Marbles, Harvard University Press, Cambridge and Massachusetts, 1984; Jacob Rotheberg, 'Descensus ad Terram': The Acquisition and Reception of the Elgin Marbles, Arcade, New York, 1997; Christopher Hitchens, The Elgin Marbles: Should They Be Returned to Greece?, Verso, New York, 
1998; Christopher Hitchens, Imperial Spoils: The Curious Case of the Elgin Marbles, Hill and Wang, New York, 1988.

${ }^{30}$ See Yannis Hamilakis, The Nation and Its Ruins: Antiquity, Archaeology and National Imagination in Greece, Oxford University Press, Oxford, 2007, p268.

${ }^{31}$ William St. Clair, Lord Elgin and the Marbles, Oxford University Press, London, 1967, p101.

${ }^{32}$ Hitchens, The Elgin Marbles: Should They Be Returned to Greece?, p82.

${ }^{33}$ Cressida Fforde, Jane Hubert and Paul Turnbull (eds), The Dead and their Possessions: Repatriation in Principle, Policy and Practice, Routledge, London, 2004, p210.

${ }^{34}$ Cuno, Who Owns Antiquity?, pxxxii.

${ }^{35}$ See Robert Aldrich, 'Colonial Museums in a Postcolonial Europe', in African and Black Diaspora: An International Journal, vol 2, no 2, 2009, pp137-156.

${ }^{36}$ ibid.

${ }^{37}$ British Museum, Policy on Acquisitions (Online). Available: http:// www.britishmuseum.org/pdf/Acquisitions.pdf (Accessed 11 Apr. 2010).

${ }^{38}$ ibid.

${ }^{39}$ Quoted in Moira G. Simpson, Making Representations: Museums in the Post-colonial Era, Routledge, London, 2001, p228.

${ }^{40}$ Quoted in Charlotte Higgins, 'Into Africa: British Museum's Reply to Ownership Debate,' The Guardian, 13 April 2006.

${ }^{41}$ Simpson, Making Representations: Museums in the Post-colonial Era, p246.

42 'Briton of the Year,' The Times, 27 December 2008.

${ }^{43}$ Quoted in Alan Riding, 'British Museum, at 250, Heads to Calmer Waters,' The New York Times, 24 June 2003.

${ }^{44}$ Quoted in Higgins, 'Into Africa: British Museum's Reply to Ownership Debate,' The Guardian, 13 April 2006.

45 ibid.

${ }^{46}$ ibid.

${ }^{47}$ See 'Museum of the World for the World: London, United Kingdom and Beyond', in British Museum Review, April 2004-March 2006, p21.

${ }^{48}$ Greenfield, The Return of Cultural Treasures, p103.

${ }^{49}$ ibid, p336.

50 'Ruling Tightens Grip on Parthenon Marbles,' The Guardian, 27 May 2005.

${ }^{51}$ See Louise Jury, 'Hidden Treasures Shown in Restored British Museum,' The Independent, 11 December 2003.

${ }^{52}$ Cuno, Who Owns Antiquity?, pxxxv.

${ }^{53}$ Christopher Hitchens challenges this view in The Elgin Marbles: Should They Be Returned to Greece?, pvii.

${ }^{54}$ Dorothy King, The Elgin Marbles, Hutchinson, London, 2006, p 314.

${ }^{55}$ See British Objections Answered (Online). Available: http:// www.greece.org/Parthenon/marbles/answers.htm (Accessed 11 Apr.2010).

${ }^{56}$ Cuno, Who Owns Antiquity?, p10.

${ }^{57}$ See Hitchens, The Elgin Marbles: Should They Be Returned to Greece?; Greenfield, The Return of Cultural Treasures; R.F Rhodes (ed), The Acquisition and Exhibition of Classical Antiquities: Professional, Legal and Ethical Perspectives, Notre Dame University Press, Notre Dame, 2007.

${ }^{58}$ The website of the New Acropolis Museum can be found at http:/ / www.newacropolismuseum.gr/eng/ (Accessed 11 Apr. 2010); also see 'Acropolis Museum Opens Amid Renewed Debate over Elgin Marbles,' Archaeology, 19 June 2009.

${ }^{59}$ Rachel Campbell-Johnston, 'Briton of the Year: Neil MacGregor,' The Times, 27 December 2008.

${ }^{60}$ Philip L. Kohl, 'Nationalism and Archaeology: On the Constructions of Nations and the Reconstructions of the Remote Past', in Annual Review of Anthropology, vol 27, 1998, p235.

${ }^{61}$ Quoted in Cuno, Who Owns Antiquity?, pxxxii.

${ }^{62}$ Quoted in Kate Fitz Gibbon, Who Owns the Past? Cultural Policy, Cultural Property and the Law, Rutgers University Press, Brunswick, 2005, p113.

${ }^{63}$ Quoted in Richard Girling, 'King Tut Tut Tut,' The Sunday Times, 22 May 2005; Cuno, Who Owns Antiquity?, pxxxii.

${ }^{64} \mathrm{See}$, for example, the following webpage: http:/ / www.arm.arc.co.uk/art/stolen/stolenIndex1.html (Accessed 11 Apr. 2010).

${ }^{65}$ John Henry Merryman, Imperialism, Art and Restitution, Cambridge University Press, New York, 2006, p176.

${ }^{66}$ For an explanation of 'unprovenanced' antiquities, see Colin Renfrew, Loot, Legitimacy and Ownership: The Ethical Crisis in Archaeology, pp9-12.

${ }^{67}$ Cuno, Who Owns Antiquity?, pp9-10.

${ }^{68}$ Simpson, Making Representations: Museums in the Post-colonial Era, p1. 